\title{
Air Pollution from Livestock Farms Is Associated with Airway Obstruction in Neighboring Residents
}

\author{
Floor Borlée ${ }^{1,2}$, C. Joris Yzermans ${ }^{2}$, Bernadette Aalders ${ }^{3}$, Jos Rooijackers ${ }^{3}$, Esmeralda Krop ${ }^{1}$, \\ Catharina B. M. Maassen ${ }^{4}$, François Schellevis ${ }^{2,5}$, Bert Brunekreef ${ }^{1,6}$, Dick Heederik ${ }^{1}$, and Lidwien A. M. Smit ${ }^{1}$ \\ ${ }^{1}$ Institute for Risk Assessment Sciences, Utrecht University, the Netherlands; ${ }^{2}$ Netherlands Institute for Health Services Research, \\ Utrecht, the Netherlands; ${ }^{3}$ Netherlands Expertise Centre for Occupational Respiratory Disorders, Utrecht, the Netherlands; ${ }^{4}$ Centre for \\ Infectious Disease Control, National Institute for Public Health and the Environment, Bilthoven, the Netherlands; ${ }^{5}$ Department of General \\ Practice \& Elderly Care Medicine, Amsterdam Public Health Research Institute, Vrije Universiteit, University Medical Center, Amsterdam, \\ the Netherlands; and ${ }^{6}$ Julius Center for Health Sciences and Primary Care, University Medical Center, Utrecht, the Netherlands
}

\section{Abstract}

Rationale: Livestock farm emissions may not only affect respiratory health of farmers but also of neighboring residents.

Objectives: To explore associations between spatial and temporal variation in pollutant emissions from livestock farms and lung function in a general, nonfarming, rural population in the Netherlands.

Methods: We conducted a cross-sectional study in 2,308 adults (age, 20-72 yr). A pulmonary function test was performed measuring prebronchodilator and post-bronchodilator $\mathrm{FEV}_{1}$, FVC, $\mathrm{FEV}_{1} / \mathrm{FVC}$, and maximum mid-expiratory flow (MMEF). Spatial exposure was assessed as (1) number of farms within $500 \mathrm{~m}$ and 1,000 $\mathrm{m}$ of the home, (2) distance to the nearest farm, and (3) modeled annual average fine dust emissions from farms within $500 \mathrm{~m}$ and $1,000 \mathrm{~m}$ of the home address. Temporal exposure was assessed as week-average ambient particulate matter $<10 \mu \mathrm{m}$ in diameter and ammonia $\left(\mathrm{NH}_{3}\right)$ concentrations before lung function measurements. Data were analyzed with generalized additive models (smoothing).

Measurements and Main Results: A negative association was found between the number of livestock farms within a 1,000 -m buffer from the home address and MMEF, which was more pronounced in participants without atopy. No associations were found with other spatial exposure variables. Week-average particulate matter $<10 \mu \mathrm{m}$ in diameter and $\mathrm{NH}_{3}$ levels were negatively associated with $\mathrm{FEV}_{1}$, $\mathrm{FEV}_{1} / \mathrm{FVC}$, and MMEF. In a two-pollutant model, only $\mathrm{NH}_{3}$ remained associated. A $25-\mu \mathrm{g} / \mathrm{m}^{3}$ increase in $\mathrm{NH}_{3}$ was associated with a $2.22 \%$ lower $\mathrm{FEV}_{1}(95 \%$ confidence interval, -3.69 to -0.74$)$, $\mathrm{FEV}_{1} / \mathrm{FVC}$ of $-1.12 \%$ ( -1.96 to -0.28$)$, and MMEF of $-5.67 \%$ $(-8.80$ to -2.55$)$.

Conclusions: Spatial and temporal variation in livestock air pollution emissions are associated with lung function deficits in nonfarming residents.

Keywords: livestock farm; lung function; air pollution; respiratory health; residents
Recent studies have highlighted the large contribution of agriculture to fine particulate matter (PM) air pollution, and the public health impact that may result from agricultural emissions (1-4). In the Netherlands, a small country with one of the highest population densities in the world and one of the highest livestock farm densities, neighboring residents are concerned about potential health risks of farm emissions (5).The air inside livestock farms contains high levels of (organic) dust, which is known to lead to adverse respiratory health effects in those occupationally exposed $(6,7)$. Livestock farms may also emit air pollutants into the atmosphere, consisting of a mixture of gases, such as ammonia $\left(\mathrm{NH}_{3}\right)$

(Received in original form January 4, 2017; accepted in final form May 9, 2017)

The Livestock Farming and Neighboring Residents' Health study was funded by the Ministry of Health, Welfare and Sports and the Ministry of Economic Affairs of the Netherlands, and supported by a grant from the Lung Foundation Netherlands (3.2.11.022).

Author Contributions: F.B., C.J.Y., D.H., and L.A.M.S. conceived and designed the study. F.B., E.K., and B.A. coordinated and conducted the medical examination. F.B. analyzed the data and drafted the manuscript. F.B., C.J.Y., B.A., J.R., E.K., C.B.M.M., F.S., B.B., D.H., and L.A.M.S. contributed to the interpretation of the results, critically reviewed the manuscript, and approved the final version before submission.

Correspondence and requests for reprints should be addressed to Lidwien A. M. Smit, Ph.D., Institute for Risk Assessment Sciences, Yalelaan 2, 3584 CM, Utrecht, the Netherlands. E-mail: I.a.smit@uu.n

This article has an online supplement, which is accessible from this issue's table of contents at www.atsjournals.org

Am J Respir Crit Care Med Vol 196, Iss 9, pp 1152-1161, Nov 1, 2017

Copyright $\odot 2017$ by the American Thoracic Society

Originally Published in Press as DOI: 10.1164/rccm.201701-00210C on May 10, 2017

Internet address: www.atsjournals.org 


\section{At a Glance Commentary}

\section{Scientific Knowledge on the}

Subject: The air inside livestock farms contains high levels of dust and gases, which can affect respiratory health in occupational settings. Several air pollutants are emitted into the atmosphere, including such gases as ammonia, and particulate matter contaminated with (parts of) microorganisms. However, little is known about health risks for neighboring residents that may result from such agricultural emissions.

\section{What This Study Adds to the}

Field: This large-scale populationbased study shows that air pollution from livestock farms is associated with obstructive lung function changes in neighboring residents. We found a negative association between farm density around the home address and lung function. In addition, lung function was lower when measured after weeks with higher ambient ammonia levels. Almost all ammonia emissions result from agricultural activities. Associations were mainly observed with lung function parameters, which are indicative of airway obstruction. Our results indicate that spatial and temporal variation in livestock farm emissions are related to obstructive respiratory effects.

and hydrogen sulfide $\left(\mathrm{H}_{2} \mathrm{~S}\right)$, and $\mathrm{PM}$ contaminated with microorganisms and toxins, such as endotoxins: cell-wall components of gram-negative bacteria ( 8 , 9). Raised endotoxin levels were measured up to $200 \mathrm{~m}$ downwind from farms $(10,11)$. $\mathrm{NH}_{3}$ is an irritant gas that is formed by enzymes in animal waste, and used as a marker for livestock farm emissions (12). $\mathrm{NH}_{3}$ is also an important precursor of secondary inorganic aerosols (SIA) and highly contributes to atmospheric PM concentrations of, among others, $\mathrm{PM}<10 \mu \mathrm{m}$ in diameter $\left(\mathrm{PM}_{10}\right)$ and $\mathrm{PM}<2.5 \mu \mathrm{m}$ in diameter $\left(\mathrm{PM}_{2.5}\right)$, of which especially $\mathrm{PM}_{2.5}$ can be transported over great distances (4).

Despite the substantial contribution of livestock farming to ambient air pollution, potential respiratory health risks have been poorly studied. Three longitudinal panel studies have been conducted in the United States. Two were conducted among 51 children with asthma and reported a temporal effect of $\mathrm{NH}_{3}$ and $\mathrm{PM}_{2.5}$ exposure on $\mathrm{FEV}_{1}(12,13)$. The other panel study also found a temporal effect of farm-related pollutants on self-reported respiratory symptoms and $\mathrm{FEV}_{1}$ in 101 adults (14). Two other American studies described spatial associations between residential proximity to livestock farms and selfreported respiratory effects $(15,16)$.

Studies from Europe have been conducted in Germany and the Netherlands. A cross-sectional German study found a decrease in $\mathrm{FEV}_{1}$ in adults with more than 12 stables within $500 \mathrm{~m}$ of the home address (17), and among subjects exposed to higher annual $\mathrm{NH}_{3}$ levels (18). In the same area a cross-sectional study among 3,867 children found an association between asthmatic symptoms and modeled endotoxin exposure among children of parents with atopy (19). Conversely, two Dutch studies found inverse associations between livestock farm proximity and asthma and chronic obstructive pulmonary disease (COPD) prevalence using medical records and self-reported data $(20,21)$. However, patients with COPD reported more symptoms in areas with high farm density $(20,22)$.

Thus, only a limited number of studies measured pulmonary function in neighboring residents, and most studies focused on spatial variation (e.g., distance to the nearest farm). However, we expect that time-varying exposure to air pollutants resulting from agricultural activities also plays a role. The current study aims to explore associations between proxies of both temporal and spatial variation in air pollution from livestock farms and lung function in a general, nonfarming population of 2,308 adults in the Netherlands. Results presented in this manuscript are part of the Livestock Farming and Neighboring Residents' Health study and have been previously presented as abstracts $(23,24)$.

\section{Methods}

\section{Study Population and Design}

A questionnaire survey was conducted among patients of 21 general practitioner practices resulting in 14,875 participating adults (53.4\% response) from the general population as described previously (20). Subjects who were working or living on a farm $(\mathrm{n}=712 ; 4.8 \%)$ were excluded. Questionnaire respondents who were willing to participate in a follow-up study were eligible for a medical examination $(\mathrm{n}=8,714)$. Based on their home addresses, 12 temporary research centers were established (Figure 1). Between March 2014 and February 2015, all participants living within a distance of approximately $10 \mathrm{~km}$ of a temporary research center $(n=7,180)$ were invited to the nearest research center for medical examination, which resulted in 2,494 participants (response, 34.7\%) (25). Nonresponse was analyzed by comparing characteristics and associations between respiratory health indicators and livestock exposure in different population subsets. The study protocol (no. 13/533) was approved by the Medical Ethical Committee of the University Medical Centre Utrecht. All 2,494 participants signed informed consent.

\section{Medical Examination}

Population characteristics were collected with an extended questionnaire. Atopy was defined as the presence of specific serum $\operatorname{IgE}$ antibodies to one or more common allergens (house dust mite, grass, cat, and $\operatorname{dog}$ ) and/or a total IgE higher than $100 \mathrm{IU} / \mathrm{ml}$ (26). Bronchodilator (BD) spirometry (pre-BD and post-BD) was conducted. $\mathrm{FEV}_{1}, \mathrm{FVC}, \mathrm{FEV}_{1} / \mathrm{FVC}$, and maximum mid-expiratory flow (MMEF) were expressed as percentage predicted based on the Global Lung Function Initiative 2012 reference Equations (27). COPD was defined as a post-BD measurement of $\mathrm{FEV}_{1} / \mathrm{FVC}$ below the lower limit of normal and/or a post-BD measurement of $\mathrm{FEV}_{1} / \mathrm{FVC}$ less than 0.70 (Global Initiative for Chronic Obstructive Lung Disease) (25).

\section{Spatial and Temporal Livestock Farm Exposure Proxies}

An aim of the current study is to replicate the association between farm density around the home and lung function in German adults (17). In addition, other spatial and temporal exposure proxies were considered. The following spatial livestock farm exposure proxies were studied for each subject: (1) total number of farms within 500 and $1,000 \mathrm{~m}$; (2) distance in meters to the nearest farm (general and specific animal farms: pigs, poultry, cattle, goats, 


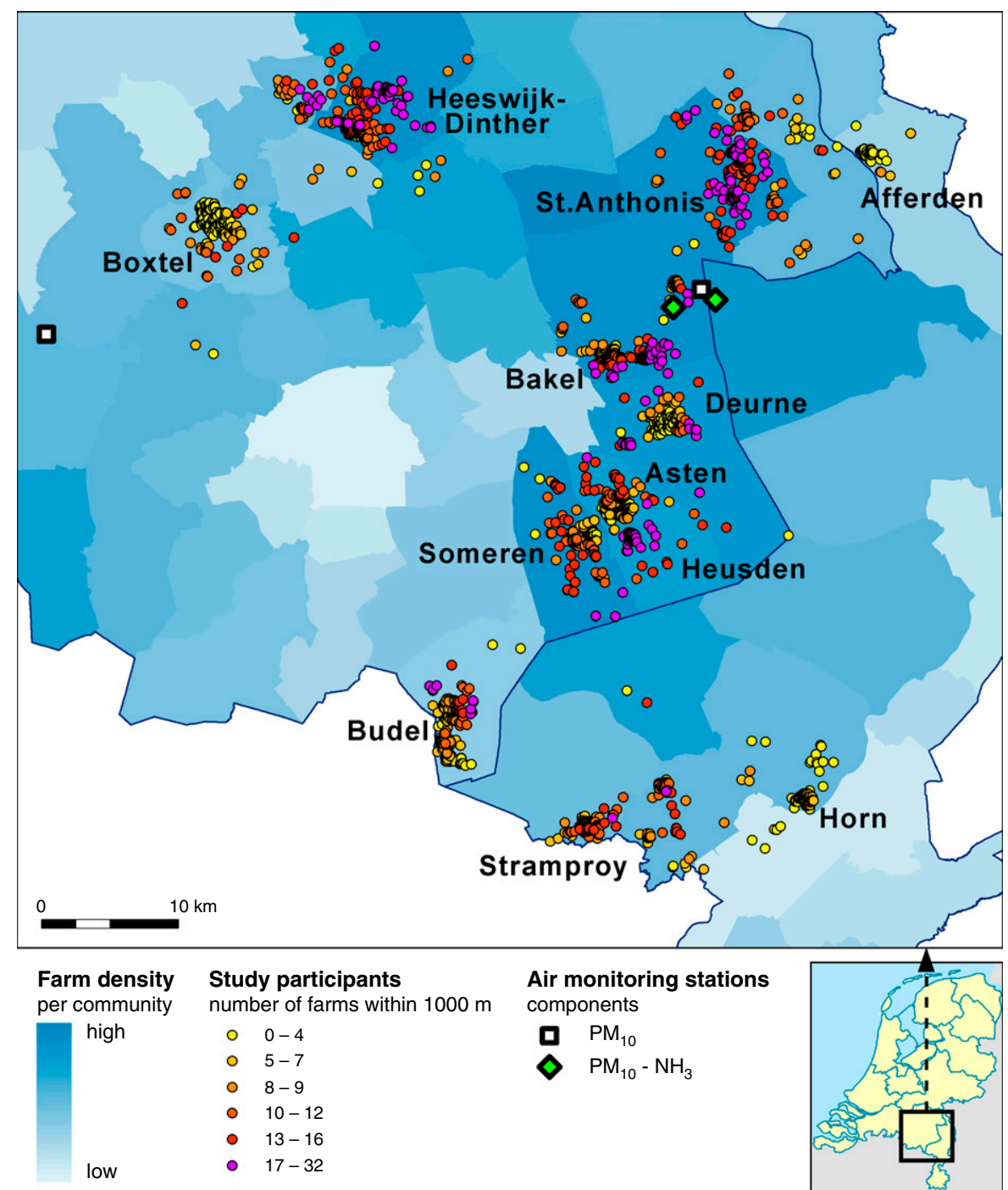

Figure 1. Map of the study area. $\mathrm{PM}_{10}=$ particulate matter $<10 \mu \mathrm{m}$ in diameter.

and mink); and (3) inverse-distance weighted fine dust emissions from all farms within $500 \mathrm{~m}$ and $1,000 \mathrm{~m}$, as described previously (21). Ambient $\mathrm{NH}_{3}$ and $\mathrm{PM}_{10}$ levels before the spirometry measurement were studied as temporal exposure proxies. Average daily ambient $\mathrm{NH}_{3}$ and $\mathrm{PM}_{10}$ levels were obtained from air monitoring stations located in the study area, which are part of the Dutch Air Quality Monitoring Network (28).

\section{Statistical Analysis}

Relationships between spirometry variables and livestock farm exposure variables (spatial and temporal) were studied using a penalized regression spline using the (default) "thin plate" basis as implemented in the mixed generalized additive model computation vehicle $\mathrm{R}$ package. Based on the results of the spline analyses, exposure cutoff values were chosen for further analyses. Multiple linear regression analyses were used to study associations between these dichotomized exposure variables and spirometry values. For all these analyses pre-BD spirometry values were used. These models were adjusted for smoking habits, living on a farm during childhood, and growing up in the study area.

Multicollinearity between confounders was checked with Spearman rank correlation and variance inflation factors.

Sensitivity analyses were conducted to investigate the effect of spirometry technician, influenza-season, humidity, temperature, and traffic-related air pollution at the home address of $\mathrm{NO}_{2}, \mathrm{PM}_{2.5}$, and
$\mathrm{PM}_{2.5}$ absorbance (soot) using land use regression models from the ESCAPE (European Study of Cohorts for Air Pollution Effects) project $(29,30)$. In addition, analyses were stratified for atopy, COPD (based on spirometry [Global Initiative for Chronic Obstructive Lung Disease and/or lower limit of normal]), asthma, and smoking habits and interaction between these groups and exposure variables was tested.

More details on the study methodology are provided in the online supplement.

\section{Results}

\section{Study Population Characteristics}

The medical examination was conducted in 2,494 persons aged 20-72 years, including more females (54.6\%) than males (Table 1). In total, 837 individuals (33.6\%) reported a farm childhood and 1,871 (75.0\%) were born in the study area. Only subjects with lung function measurements with sufficient quality were included in the analyses, which resulted in 2,308 pre-BD measurements and 2,169 post-BD measurements. Based on spirometry results we found indication of reversibility in $4.1 \%$ and COPD in $10.9 \%$ of all participants.

\section{Nonresponse Analysis}

Differences in personal characteristics of different population subsets were found (e.g., age, sex, self-reported morbidity, distance to farms) indicating that selectionbias could have played a role (Table 2; see online supplement). However, associations between farm exposure estimates and respiratory morbidity based on self-reported data in different population subsets (the source population, the population that participated in the questionnaire survey, the population invited for the medical examination, and the population that participated in the medical examination) showed similar associations, in terms of direction and magnitude, with overlapping confidence intervals (CIs) (see Table E3 in the online supplement).

\section{Association between Spatial Variation in Livestock Exposure and Lung Function}

Farms located in the study area are a mix of small farms with relatively few animals to large farms with thousands of animals (see Table E1). Smoothed plots suggested a nonlinear negative association between 
Table 1. General Characteristics of the Study Population

\section{Characteristics}

Total Population $(n=2,494)$

Age, yr
Female
BMI $^{*}$
Never smoker
Ever smoker
Current smoker
Pack-years
Education level
Low
Medium
High

$54.7 \pm 11.0$

$1,363(54.6)$

$27.1 \pm 4.3$

$1,122(45.0)$

$1,112(44.6)$

$252(10.1)$

$18.1 \pm 17.9$

$607(24.3)$

$1,112(44.6)$

$746(29.9)$

$837(33.6)$

$1,871(75.0)$

Grown up in study area

Lung function characteristics

Pre-BD measurement \% predicted $(n=2,308)^{\ddagger}$

FEV

FVC

$\mathrm{FEV}_{1} / \mathrm{FVC}$

MMEF

Post-BD measurement \% predicted $(n=2,169)^{\ddagger}$

FEV 1

FVC

$\mathrm{FEV}_{1} / \mathrm{FVC}$

MMEF

Health characteristics $\left(n=2,037^{\ddagger}\right.$, and subjects with atopy measurement $n=2,443$ )

Reversibility ${ }^{\S}$

COPD"

Atopy

$99.0 \pm 15.4$

$102.9 \pm 13.0$

$95.7 \pm 8.7$

$93.5 \pm 32.8$

$102.0 \pm 14.5$

$102.9 \pm 12.6$

$98.7 \pm 8.4$

$105.9 \pm 35.1$

$83(4.1)$

$222(10.9)$

$727(29.8)$

Definition of abbreviations: $\mathrm{BD}=$ bronchodilator; $\mathrm{BMI}=$ body mass index; $\mathrm{COPD}=$ chronic obstructive pulmonary disease; $\mathrm{MMEF}=$ maximum mid-expiratory flow.

Data are presented as mean \pm SD or $n(\%)$. Education levels: low—lower secondary school or less; mediumintermediate vocational education or upper secondary school; high—higher education or university.

${ }^{*} \mathrm{BMl}=$ mass $(\mathrm{kg}) /(\text { height }[\mathrm{m}])^{2}$.

${ }^{\dagger}$ Mean pack-years for subjects who ever smoked.

${ }^{\ddagger}$ Lung function measurements with quality $\mathrm{C}$ or better. Reversibility and COPD were analyzed in

subjects with before and after measurements with a sufficient quality $(n=2,037)$.

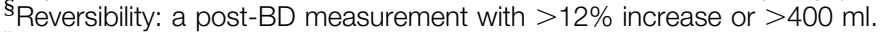

"COPD: a post-BD measurement of $\mathrm{FEV}_{1} / \mathrm{FVC}$ below the lower limit of normal and/or a post-BD

measurement of $\mathrm{FEV}_{1} / \mathrm{FVC}<0.70$ (Global Initiative for Chronic Obstructive Lung Disease).

the number of farms in a $1,000-\mathrm{m}$ radius and $\mathrm{FEV}_{1}, \mathrm{FEV}_{1} / \mathrm{FVC}$, and $\mathrm{MMEF}$

(Figure 2). The association was statistically significant for MMEF. No clear association was found for FVC, indicating that in particular obstructive lung function changes occurred. No associations were found with farm density for specific animal species or with the other spatial exposure proxies including distance to the nearest farm (general and specific animal farms) and modeled annual average fine dust emissions from farms within $500 \mathrm{~m}$ and $1,000 \mathrm{~m}$. Spirometry results expressed as $z$ scores showed minimal differences compared with results presented as \% predicted values (see Figure E1).

Adjustment for week-average $\mathrm{NH}_{3}$ and $\mathrm{PM}_{10}$ levels at the time of the medical evaluation resulted in only minor changes of the association between farm density and lung function (dashed and dotted lines in Figure 2).

Based on the shape of the splines, a cutoff value of 17 farms or more was chosen to compare so-called hotspot areas with a high farm density, with lower farm density areas. This cutoff value was based on a visual inspection of the smoothed plots; around 17 farms within $1,000 \mathrm{~m}$, there is a turning point where the $\%$ predicted value is lower than the $\%$ predicted value at 0 farms. In total $11.3 \%$ participants lived in a hotspot and they had a $4.5 \%$ lower MMEF (95\% CI, -8.64 to -0.36 ), and a $1.86 \%$ lower $\mathrm{FEV}_{1}(95 \% \mathrm{CI},-3.80$ to 0.09$)$ than participants from lower farm density areas. Adjustment for spirometry technician, influenza-season, humidity, temperature, and traffic-related air pollution $\left(\mathrm{NO}_{2}\right.$,
$\mathrm{PM}_{2.5}$, and soot) had minor effects on the association between lung function and hotspot (see sensitivity analyses in Figure E2). No association between living in a hotspot and lung function was observed when patients with COPD were removed from the analyses. Associations were also stronger when analyses were restricted to subgroups of subjects without atopy and ever smokers.

A significant interaction was observed between atopy and hotspot in models with lung function variables $\mathrm{FEV}_{1} / \mathrm{FVC}$ and MMEF $(P<0.05)$, indicating significantly different associations between living in a hotspot and lung function among subjects without and with atopy. Minor changes were observed when atopy was defined as specific serum $\operatorname{IgE}$ to one or more common allergens (instead of the combination specific serum IgE and/or total IgE $>100 \mathrm{IU} / \mathrm{ml}$ ): associations were still stronger when analyses were restricted to subjects without atopy and (borderline) significant interaction was observed between atopy and hotspot in $\mathrm{FEV}_{1}$ /FVC and MMEF models (results not shown).

\section{Association between Temporal Variation in Livestock Exposure and Lung Function}

During the period the medical survey took place, ambient $\mathrm{NH}_{3}$ levels ranged from 1.6 to $52.5 \mu \mathrm{g} / \mathrm{m}^{3}$ (week-average values) (Figure 3) with a median $\mathrm{NH}_{3}$ level of $16.3 \mu \mathrm{g} / \mathrm{m}^{3}$. Higher $\mathrm{NH}_{3}$ peaks were observed in spring and summer compared with autumn and winter, most likely as a result of manure spreading. Ambient $\mathrm{PM}_{10}$ levels ranged from 9.6 to $54.0 \mu \mathrm{g} / \mathrm{m}^{3}$ (week-average values) (Figure 3 ) with a median $\mathrm{PM}_{10}$ level of $18.9 \mu \mathrm{g} / \mathrm{m}^{3}$. Correlation between week-average $\mathrm{NH}_{3}$ and $\mathrm{PM}_{10}$ levels was moderately strong (Pearson $r=0.64$ ). Smoothed plots indicated negative linear associations between all lung function variables and week-average $\mathrm{NH}_{3}$ level before the lung function measurement (Figure 4).

Significant associations were found for $\mathrm{FEV}_{1}, \mathrm{FEV}_{1} / \mathrm{FVC}$, and MMEF, which are indicators of airway obstruction. Other lags for $\mathrm{NH}_{3}$ (lag 0-2 d) resulted generally in weaker, but often statistically significant, associations (see Figure E3A). Adjustment for farm density around the home address did not change the association between lung function and $\mathrm{NH}_{3}$ (Figure 4). Spirometry results expressed as $z$ scores 
Table 2. Comparison of Characteristics of Consenting versus Nonconsenting Subjects

\begin{tabular}{|c|c|c|c|c|c|c|}
\hline & \multicolumn{3}{|c|}{ Agreed to be Contacted for Follow-up Study } & \multicolumn{3}{|c|}{ Participated in Medical Examination } \\
\hline & Yes & No & $\begin{array}{l}\text { Adjusted OR } \\
(95 \% \mathrm{Cl})\end{array}$ & Yes & No & $\begin{array}{l}\text { Adjusted OR } \\
(95 \% \mathrm{Cl})\end{array}$ \\
\hline Subjects, $\mathrm{n}$ & 8,714 & 5,449 & & 2,494 & 4,686 & \\
\hline Age, mean (SD), $\mathrm{yr}^{\star}$ & $51.1(12.9)$ & $49.8(13.9)$ & $1.07(1.04-1.10)$ & $54.7(11.0)$ & $49.1(13.3)$ & $1.49(1.43-1.56)$ \\
\hline Female, \% & 53.0 & 54.7 & $0.94(0.88-1.00)$ & 54.6 & 52.2 & $1.20(1.08-1.32)$ \\
\hline Never smoker, \% & 45.5 & 49.1 & 1 & 45.0 & 46.4 & 1 \\
\hline Ever smoker, \% & 38.8 & 31.4 & $1.28(1.18-1.38)$ & 44.6 & 35.7 & $1.20(1.08-1.33)$ \\
\hline Current smoker, \% & 15.4 & 17.4 & $0.94(0.86-1.04)$ & 10.1 & 17.7 & $0.97(0.86-1.08)$ \\
\hline \multicolumn{7}{|l|}{ Self-reported morbidity, \% } \\
\hline Current asthma & 5.9 & 4.3 & 1.46 (1.24-1.71) & 4.9 & 5.9 & $0.94(0.75-1.18)$ \\
\hline Ever asthma & 7.7 & 6.3 & $1.29(1.12-1.48)$ & 6.3 & 8.0 & $0.90(0.74-1.10)$ \\
\hline COPD & 4.7 & 4.0 & $1.14(0.96-1.35)$ & 5.1 & 4.3 & $1.03(0.81-1.30)$ \\
\hline Nasal allergies & 24.3 & 19.0 & $1.42(1.30-1.54)$ & 24.6 & 23.7 & $1.15(1.02-1.30)$ \\
\hline \multicolumn{7}{|l|}{ Morbidity based on EMR } \\
\hline Subject complete EMR, $\mathrm{n}$ & 6,859 & 4,390 & & 1,936 & 3,443 & \\
\hline Asthma (ICPC R96), \% & 7.2 & 6.1 & $1.21(1.03-1.41)$ & 5.9 & 6.9 & $0.88(0.69-1.12)$ \\
\hline COPD (ICPC R91 and/or R95), \% & 3.7 & 3.3 & $1.05(0.85-1.30)$ & 3.6 & 3.4 & $0.80(0.59-1.10)$ \\
\hline Allergic rhinitis (ICPC R97), \% & 7.1 & 5.4 & 1.40 (1.19-1.65) & 6.9 & 6.9 & $1.18(0.95-1.50)$ \\
\hline \multicolumn{7}{|l|}{ Exposure } \\
\hline \multicolumn{7}{|c|}{ Mean (SD) distance to the nearest farm, $\mathrm{m}$} \\
\hline Any farm ${ }^{\top}$ & $487(277)$ & $493(271)$ & $0.99(0.98-1.00)$ & $439(257)$ & $486(278)$ & $0.94(0.92-0.95)$ \\
\hline Pig farm ${ }^{\dagger}$ & 767 (369) & 775 (765) & $0.99(0.98-1.00)$ & $692(346)$ & 763 (354) & $0.94(0.93-0.95)$ \\
\hline Poultry farm ${ }^{\dagger}$ & $955(456)$ & $967(457)$ & $0.99(0.99-1.00)$ & $874(409)$ & $909(413)$ & $0.98(0.97-0.99)$ \\
\hline Cattle farm ${ }^{\dagger}$ & $587(315)$ & $598(311)$ & $0.99(0.98-1.00)$ & $503(273)$ & $552(284)$ & $0.94(0.92-0.95)$ \\
\hline Goat farm ${ }^{\dagger}$ & $1,648(473)$ & $1,642(474)$ & $1.00(0.99-1.01)$ & $1,602(504)$ & $1,635(481)$ & $0.98(0.97-0.99)$ \\
\hline Mink farm ${ }^{\dagger}$ & $1,848(370)$ & $1,841(381)$ & $1.00(0.99-1.01)$ & $1,794(426)$ & $1,847(370)$ & $0.96(0.95-0.98)$ \\
\hline \multicolumn{7}{|l|}{ Mean (SD) number of livestock farms } \\
\hline Within $500 \mathrm{~m}$ radius & $1.5(1.9)$ & $1.4(1.8)$ & $1.03(1.01-1.05)$ & $1.8(2.1)$ & $1.5(1.8)$ & $1.10(1.07-1.13)$ \\
\hline Within $1,000 \mathrm{~m}$ radius & $7.9(5.5)$ & $7.9(5.6)$ & $1.00(0.99-1.01)$ & $9.3(5.9)$ & $8.1(5.6)$ & 1.04 (1.03-1.05) \\
\hline \multicolumn{7}{|l|}{$\begin{array}{l}\text { Modeled fine dust emission, } \\
\text { median, } \mathrm{g} \cdot \mathrm{yr}^{-1} \cdot \mathrm{m}^{-2}\end{array}$} \\
\hline $\begin{array}{l}\text { Weighted fine dust emission from } \\
\text { farms within } 500 \mathrm{~m}^{\ddagger}\end{array}$ & 0.02 & 0.01 & $1.01(1.00-1.02)$ & 0.07 & 0.02 & $1.04(1.03-1.05)$ \\
\hline $\begin{array}{l}\text { Weighted fine dust emission from } \\
\text { farms within } 1,000 \mathrm{~m}^{\ddagger}\end{array}$ & 1.17 & 1.18 & $1.00(0.99-1.02)$ & 1.83 & 1.33 & $1.08(1.06-1.10)$ \\
\hline
\end{tabular}

Definition of abbreviations: $\mathrm{Cl}$ = confidence interval; COPD = chronic obstructive pulmonary disease; EMR=electronic medical records; ICPC = International Classification of Primary Care; OR = odds ratio.

The likelihood of agreeing to follow-up and of being a participant is modeled for different characteristics with logistic regression. OR (95\% Cl) adjusted for age, sex, and smoking habits. Bold type indicates statistical significance $(P<0.05)$. In total, 14,163 subjects responded to the short questionnaire (20), of whom 8,714 agreed to be contacted for a follow-up study and 5,449 did not agree to be contacted. In total, 7,180 subjects were invited for a medical examination, of whom 2,494 participated and 4,686 were invited but did not participate.

${ }^{*} \mathrm{OR}(95 \% \mathrm{Cl})$ for an increase per 10 years.

${ }^{\dagger} \mathrm{OR}(95 \% \mathrm{Cl})$ for an increase per $100 \mathrm{~m}$.

${ }^{\ddagger} \mathrm{OR}(95 \% \mathrm{Cl})$ for an unit increase in log-transformed exposure.

showed minimal differences compared with results presented as \% predicted values (see Figure E4). Smoothed plots showed similar negative linear associations between all lung function variables and weekaverage $\mathrm{PM}_{10}$ (see Figure E5). However, in a two-pollutant model, only $\mathrm{NH}_{3}$ remained associated with lung function (Figure 4; see Figures E5 and E6).

Linear regression analyses showed that a change in week-average $\mathrm{NH}_{3}$ levels between the P10 and P90 $\left(25.1 \mu \mathrm{g} / \mathrm{m}^{3}\right)$ was associated with a difference in $\mathrm{FEV}_{1}$ of -2.22 (95\% CI, -3.69 to -0.74$)$, FVC of -1.07 (95\% CI, -2.33 to 0.20$), \mathrm{FEV}_{1} / \mathrm{FVC}$ of -1.12 (95\% CI, -1.96 to -0.28$)$, and MMEF of -5.67 (95\% CI, -8.80 to -2.55$)$. Adjustment for lung function technician, influenza-season, humidity, and temperature had minor effects on the association between week-average $\mathrm{NH}_{3}$ and lung function (see sensitivity analyses in Figure E6). When analyses were restricted to subjects without atopy, or ever smokers, associations became stronger. However, no significant interaction terms between atopy or smoking status and week-average $\mathrm{NH}_{3}$ levels were observed. When atopy was defined as specific serum IgE to one or more common allergens (instead of the combination: specific serum IgE and/or total $\mathrm{IgE}>100 \mathrm{IU} / \mathrm{ml}$ ), associations restricted to subject without atopy were still stronger compared with the total population (results not shown). Minor changes were observed when patients with COPD were removed.

\section{Discussion}

This large-scale population-based study shows that emissions from livestock farms are associated with a reduced lung function level of inhabitants of a rural area with high 

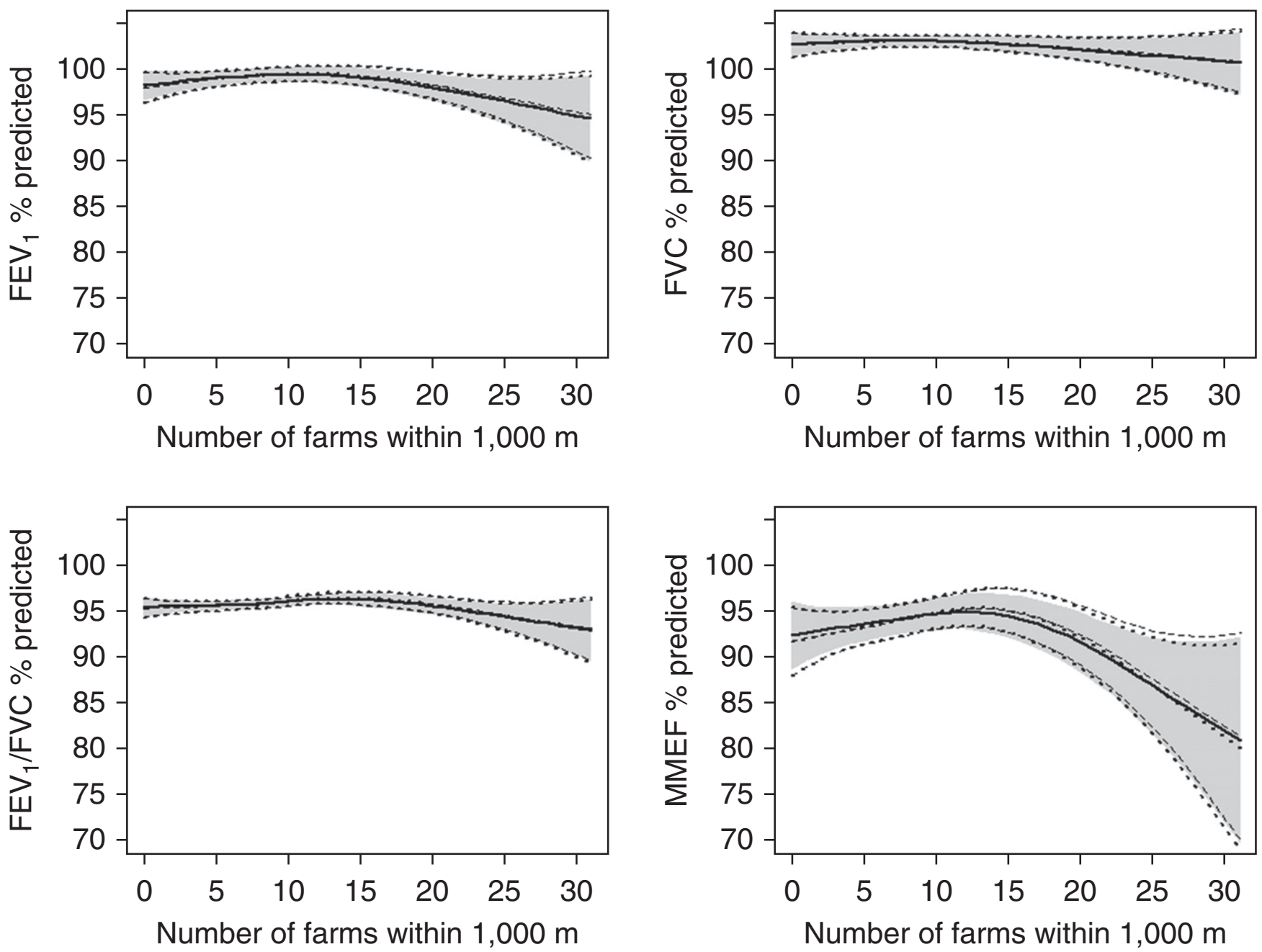

Figure 2. Association between the number of livestock farms within 1,000 $\mathrm{m}$ of the home address and lung function in 2,308 residents. Smoothed plots show the association between the number of livestock farms within 1,000 $\mathrm{m}$ of the home address and lung function. The solid lines show the shape of the smoothed plot, and the gray shading reflects the area within the 95\% confidence intervals. $P$ values of the smooth terms are: FEV ${ }_{1}, 0.116$; FVC, 0.347; FEV 1 FVC, 0.114; and maximum mid-expiratory flow (MMEF), 0.045. Adjustment for age, sex, and height was made by calculating \% predicted spirometry variables based on Global Lung Function Initiative reference values (27). Associations are also adjusted for smoking habits, being born in the study area, and farm childhood. The dashed lines show the results after further adjustment for week-average ambient ammonia $\left(\mathrm{NH}_{3} ; \mu \mathrm{g} / \mathrm{m}^{3}\right)$ levels before the lung function test. Upper and lower dashed lines reflect the upper and lower confidence limits (95\%). $P$ values of the smooth terms after adjustment for week-average ambient $\mathrm{NH}_{3}$ levels are: $\mathrm{FEV}_{1}, 0.142$; FVC, 0.355; FEV 1 /FVC, 0.106; and MMEF, 0.051. The dotted lines show the models with further adjustment for week-average ambient $\mathrm{PM}_{10}\left(\mu \mathrm{g} / \mathrm{m}^{3}\right)$ levels before the lung function test. Upper and lower dotted lines reflect the upper and lower confidence limits (95\%). $P$ values of the smooth terms after adjustment for week-average $\mathrm{PM}_{10}$ levels are: FEV $1,0.101 ; \mathrm{FVC}, 0.361 ; \mathrm{FEV} / \mathrm{FVC}$, 0.081; and MMEF, 0.030. $\mathrm{PM}_{10}=$ particulate matter $<10 \mu \mathrm{m}$ in diameter.

livestock farming density. Associations were found between lung function and both spatial and temporal livestock exposure estimates. A spatial association was found between the number of livestock farms within 1,000 $\mathrm{m}$ and MMEF. A temporal association was found between $\mathrm{FEV}_{1}$, $\mathrm{FEV}_{1} / \mathrm{FVC}$, and MMEF (three indicators of airway obstruction) and week-average ambient $\mathrm{NH}_{3}$ levels before the lung function measurements. Mutual adjustment of temporal and spatial effects did not change these associations. Our results indicate that the spatial association was especially apparent in subjects without atopy, whereas the temporal association with $\mathrm{NH}_{3}$ was observed in the whole population.

To our knowledge, this is the largest study on respiratory health of residents living in close proximity to livestock farms focused on lung function. The combination of both spatial and temporal variation in livestock farm exposure in association with lung function of residents from the general population has not been explored before. Another strength of the current study was the detailed medical information available for nonresponders, enabling a detailed nonresponse analysis. We compared associations between respiratory endpoints using electronic medical records from general practitioners and self-reported respiratory conditions and livestock-related exposure for different subpopulations. A comparison between characteristics of nonresponders and responders of the questionnaire 


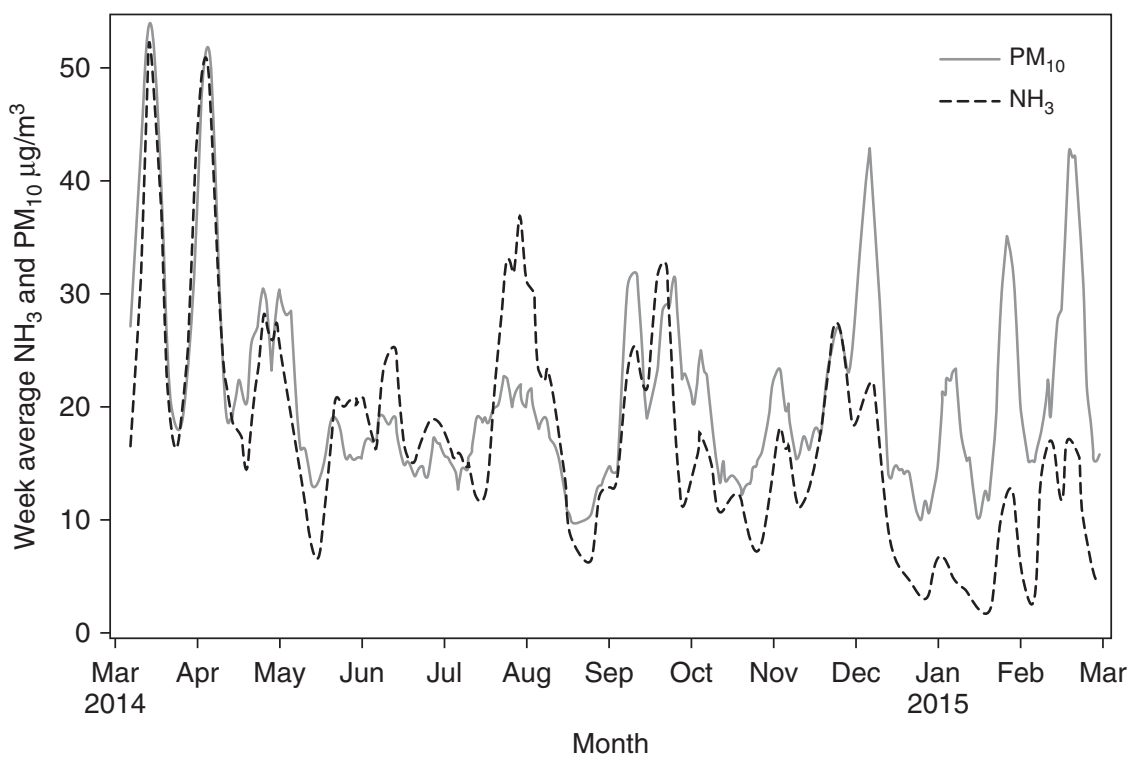

Figure 3. Week-average ambient ammonia $\left(\mathrm{NH}_{3}\right)$ and $\mathrm{PM}_{10}\left(\mu \mathrm{g} / \mathrm{m}^{3}\right)$ levels in the study area. Weekaverage ambient $\mathrm{NH}_{3}$ and $\mathrm{PM}_{10}$ concentrations were obtained from, respectively, two and four rural background monitoring stations located in the study area, which are part of the Dutch Air Quality Monitoring Network (28). Pearson correlation between week-average ambient $\mathrm{NH}_{3}$ and $\mathrm{PM}_{10}$ levels was $r=0.64$. $\mathrm{PM}_{10}=$ particulate matter $<10 \mu \mathrm{m}$ in diameter.

survey (source-population) was described before and showed differences in personal characteristics between both groups (20). However, both in the previous questionnaire survey and in the present study, selection bias did not seem to affect associations between different farm exposure estimates and prevalence of respiratory morbidity.

The Netherlands is a small country with a high population density in combination with a high livestock farm density. On an area of 41,000 $\mathrm{km}^{2}, 17$ million people live together with 105 million chickens, 12 million pigs, 4 million cows, 0.5 million goats, and 1 million mink (31). We found an association between lung function and living in areas with more than 17 farms within a 1,000-m radius and designated such areas as hotspots. This cutoff value is based on a data-driven approach, based on a visual inspection of the smoothed plots. This spatial association is consistent with results from a crosssectional study among residents from a rural area in Germany (Lower Saxony Lung Study) (17): more than 12 stables (fourth quartile) within $500 \mathrm{~m}$ of the home address was associated with a lower $\mathrm{FEV}_{1}$ $\left(-7.4 \% \mathrm{FEV}_{1 ;}\right.$ 95\% CI, -14.4 to -0.4$)$ compared with less than five stables within $500 \mathrm{~m}$ (first quartile). Annual $\mathrm{NH}_{3}$ concentrations were measured in the same study area in Germany and the number of farms within $500 \mathrm{~m}$ explained $28 \%$ of the variability of annual average outdoor $\mathrm{NH}_{3}$ concentrations (18). Subjects exposed to annual $\mathrm{NH}_{3}$ levels of $19.7 \mu \mathrm{g} / \mathrm{m}^{3}$ or higher had a lower $\mathrm{FEV}_{1}$ and $\mathrm{FEV}_{1} / \mathrm{FVC}\left(-8.2 \% \mathrm{FEV}_{1}\right.$ and $-3.3 \% \mathrm{FEV}_{1} / \mathrm{FVC}$ compared with subjects exposed to lower $\mathrm{NH}_{3}$ levels). Both the Lower Saxony Lung Study and the current study found indications for obstructive effects.

We found stronger associations when analyses were restricted to participants without atopy. A significant interaction between atopy and living in a hotspot was observed. Previous studies are inconsistent on the effect of farm exposure in subjects without atopy. A study among children from farming and nonfarming households found a negative (protective) association for atopic wheeze and endotoxin levels in matrass dust, whereas for nonatopic wheeze, there was a positive association (32). Other studies did not demonstrate differences between subject with and without atopy in the effect of endotoxin exposure on respiratory health $(33,34)$. Contrary, previous studies among farmers showed stronger associations between endotoxin exposure and respiratory health effects for sensitized than for nonsensitized farmers $(35,36)$. In addition, a German study found a positive association between endotoxin levels and asthmatic symptoms among children of parents with atopy, whereas no association was found among children of parents without atopy (19). Our study also suggested that some of the associations with hotspot exposure were restricted to patients with COPD, who may be especially susceptible to air pollutants (37). This finding is supported by a previous questionnaire study and analysis of medical records in the same study area, showing that patients with COPD living in close proximity to livestock farms reported more wheezing and inhaled corticosteroids usage, and were more often treated for exacerbations $(20,22)$.

Livestock farm emissions are a complex mixture of bioaerosols, gases, and vapors, many of which are respiratory irritants. One etiologically plausible candidate is endotoxin. Increased endotoxin concentrations have been measured around farms $(10,11)$. In addition, a larger spatial variation in endotoxin compared with $\mathrm{PM}_{10}$ concentrations was observed in ambient air measurements in the same study area and endotoxin concentrations were more strongly predicted by livestock-related characteristics in the environment (38). Previous studies among residents have also found associations between $\mathrm{H}_{2} \mathrm{~S}$ and eye irritation and respiratory symptoms (14). Guidry and coworkers (8) found spatial and temporal associations between size and distance of upwind livestock farms and $\mathrm{H}_{2} \mathrm{~S}$ levels. Because of low concentrations of $\mathrm{H}_{2} \mathrm{~S}$ and strong correlation with other pollutants, Guidry and coworkers (8) argued that health effects can probably not be attributed to $\mathrm{H}_{2} \mathrm{~S}$ alone, but to a mixture of which $\mathrm{H}_{2} \mathrm{~S}$ is part of.

Because individuals were subjected to pulmonary function tests on one occasion, but over a study period of a year (between March 2014 and February 2015), we adjusted for week-average air pollution concentrations before each individual's lung function test (39). An association was found between both week-average $\mathrm{PM}_{10}$ and $\mathrm{NH}_{3}$ levels before spirometry and lung function. In a model with mutual adjustment for $\mathrm{NH}_{3}$ and $\mathrm{PM}_{10}$, the $\mathrm{NH}_{3}$ association remained (minor change in size of effect) but the association with $\mathrm{PM}_{10}$ was no longer observed. Livestock production is the major contributor to ambient $\mathrm{NH}_{3}$ levels. We evaluated potential 

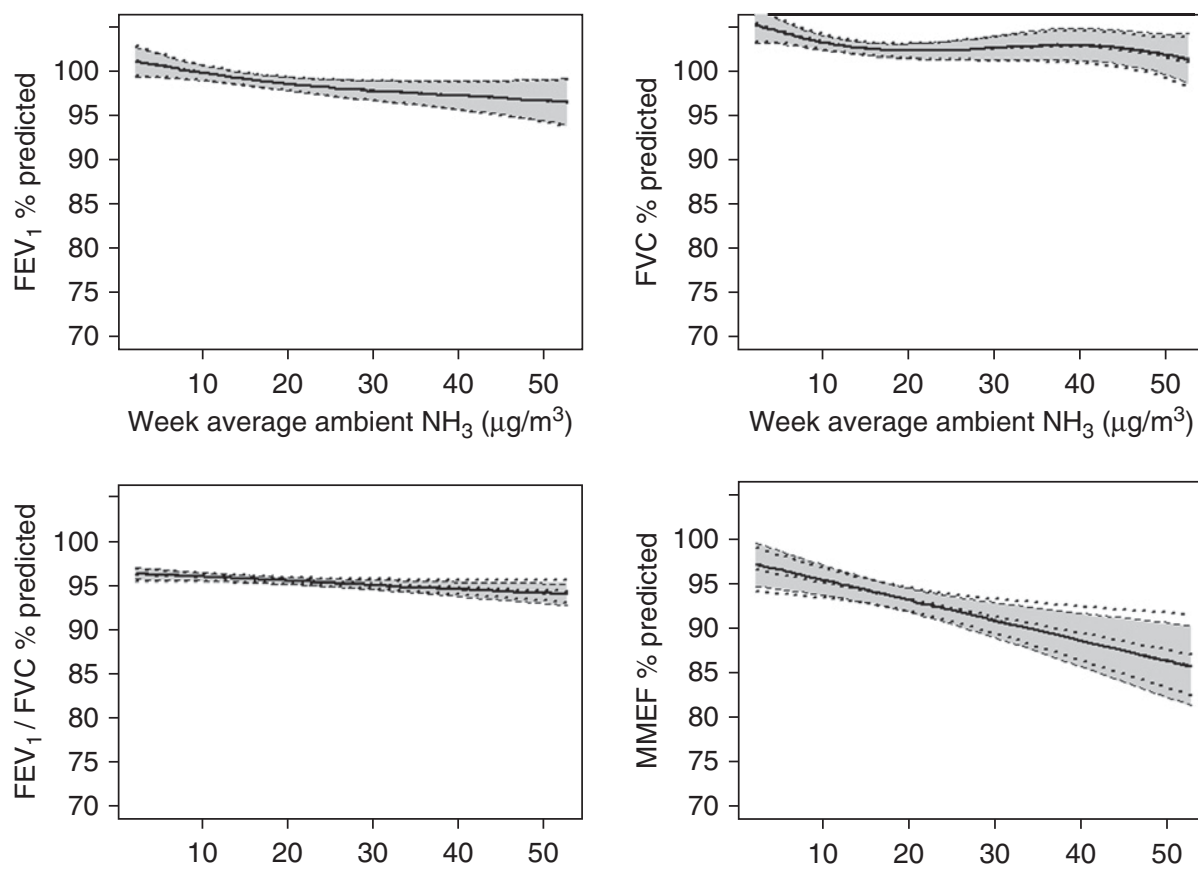

Week average ambient $\mathrm{NH}_{3}\left(\mu \mathrm{g} / \mathrm{m}^{3}\right)$

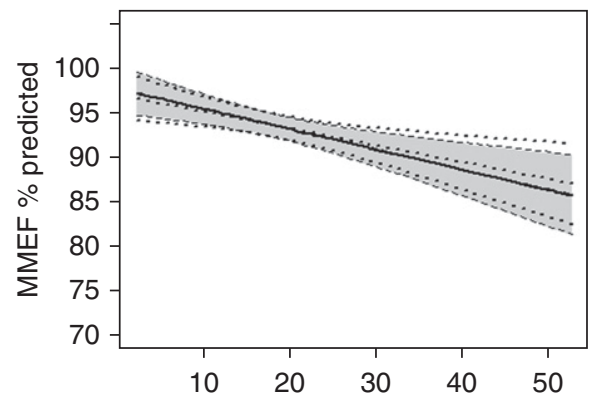

Week average ambient $\mathrm{NH}_{3}\left(\mu \mathrm{g} / \mathrm{m}^{3}\right)$

Figure 4. Associations between ambient ammonia $\left(\mathrm{NH}_{3} ; \mu \mathrm{g} / \mathrm{m}^{3}\right)$ in the week before the lung function test and lung function in 2,308 residents. Smoothed plots show the association between the weekaverage ambient $\mathrm{NH}_{3}\left(\mu \mathrm{g} / \mathrm{m}^{3}\right)$ levels before the lung function test and lung function. The solid lines show the shape of the smoothed plot, the gray shading reflects the area within the $95 \%$ confidence intervals. $P$ values of the smooth terms are: $\mathrm{FEV}_{1}, 0.012 ; \mathrm{FVC}, 0.098 ; \mathrm{FEV}_{1} / \mathrm{FVC}, 0.009$; and maximum mid-expiratory flow (MMEF), <0.001. Adjustment for age, sex, and height was made by calculating \% predicted spirometry variables based on Global Lung Function Initiative reference values (27). Associations are also adjusted for smoking habits, being born in the study area, and farm childhood. The dashed lines show the results after further adjustment for spatial exposure: number of farms within 1,000 $\mathrm{m}$ of the home address. Upper and lower dashed lines reflect the upper and lower confidence limits (95\%). $P$ values of the smooth terms after adjustment for number of farms within $1,000 \mathrm{~m}$ are: $\mathrm{FEV}_{1}, 0.015$; FVC, 0.107; FEV $/$ FVC, 0.008; and MMEF, $<0.001$. The dotted lines show the models for further adjustment for week-average ambient $\mathrm{PM}_{10}\left(\mu \mathrm{g} / \mathrm{m}^{3}\right)$ levels before the lung function test. Upper and lower dotted lines reflect the upper and lower confidence limits (95\%). $P$ values of the smooth terms after adjustment for week-average $\mathrm{PM}_{10}$ are: FEV, 0.101 ; FVC, 0.133; $\mathrm{FEV}_{1} / \mathrm{FVC}, 0.196$; and MMEF, 0.070. $\mathrm{PM}_{10}=$ particulate matter $<10 \mu \mathrm{m}$ in diameter.

confounding by correlated air pollutants and other time-variant variables, such as seasonal effects, but we do not expect that temporal variation in ambient $\mathrm{NH}_{3}$ levels is associated with other (occupational) exposures or usage of cleaning products. Therefore, we did not consider these variables as potential confounders.

The temporal association with $\mathrm{NH}_{3}$ levels corresponds to results of Loftus and coworkers (12) who conducted a panel study among 51 children with asthma living in an agricultural region of Washington State, where ammonia levels in ambient air were strongly associated with proximity to farms. Even though Loftus and coworkers (12) used a different study design (panel study with repeated measurements) and a different study population compared with our study, both studies found an association between lung function and agricultural air pollution. A 3.8\% (95\% CI, $0.2-7.3)$ decrease of $\mathrm{FEV}_{1}$ was observed per interquartile range $\left(25 \mu \mathrm{g} / \mathrm{m}^{3}\right)$ increase in previous day $\mathrm{NH}_{3}$ concentration (12). They found a smaller association with $\mathrm{PM}_{2.5}$ : $\mathrm{FEV}_{1}$ decreased by $0.9 \%$ (95\% CI, $\left.1.8-0.0\right)$ for an interquartile range increase of previous day $\mathrm{PM}_{2.5}$ levels $\left(7.9 \mu \mathrm{g} / \mathrm{m}^{3}\right)$ (13).

Because $\mathrm{NH}_{3}$ is mostly locally generated $(40,41)$, this suggests that the temporal associations with lung function were mostly driven by locally generated pollutants, represented by $\mathrm{NH}_{3}$. Considering the ambient $\mathrm{NH}_{3}$ levels during the study period (median, $16.3 \mu \mathrm{g} / \mathrm{m}^{3}$ ), it is unlikely that $\mathrm{NH}_{3}$ has a direct effect on respiratory health of residents. The threshold limit value for ammonia in an occupational setting is $25 \mathrm{ppm}\left(1,800 \mu \mathrm{g} / \mathrm{m}^{3}\right)$ (42). However, a study among farmers showed a decrease in $\mathrm{FEV}_{1}$ at levels above 7.5 ppm (43). Nonetheless, it is more plausible that ambient $\mathrm{NH}_{3}$ levels serve as a marker for airborne emissions from livestock farms and agricultural activities and that the observed decrease in lung function results from exposure to one or more copollutants, including microbial agents, such as endotoxins (9). Another explanation is that ambient $\mathrm{NH}_{3}$ concentrations are associated with SIA formation. $\mathrm{NH}_{3}$ reacts in the atmosphere with nitrogen oxides and sulfur dioxide to form solid (particulate) ammonium sulfates and nitrates, which are part of the $\mathrm{PM}_{2.5}$ fraction and can penetrate deeply into the lung (4). Secondary particle formation takes time, however, and without further studies of the local atmospheric chemistry we cannot support the likelihood of these transformations happening locally. A recent study from Barcelona suggested that significant SIA formation may take place already on an urban spatial scale (44). More detailed characterization of livestockassociated environmental exposures, including bioaerosol analysis and SIA formation, is needed.

Spatial exposure variables were based on participants' home address, but because most people do not spend 24 hours a day at home, this may lead to exposure misclassification. However, in Europe, adults spend most of their time indoors at home (56-66\%) (45), which suggests that home address might be a reasonable proxy for individual exposure. In addition, we did not take into account the influence of wind direction or wind speed on exposure. In the Netherlands, winds are slightly more often from the southwest, but south-westerly winds are also associated with less stable weather conditions favoring larger dispersion of pollutant emissions. As a result, there is usually not much difference between concentrations measured in different directions from a source. Both limitations introduce nondifferential exposure misclassification, leading to an underestimation of the effect of farm exposure. A more comprehensive method to estimate spatial exposure (e.g., with dispersion modeling or even an actual intensive air measurement network) will 
increase precision of spatial exposure. We have used central site monitoring data to represent temporal $\mathrm{NH}_{3}$ exposure, which is the usual approach in studies investigating acute effects of air pollution (37). Validation studies have reported moderately high correlations between temporal variations in ambient outdoor concentrations at the home address and at central monitoring sites for both PM and gaseous air pollutants $(46,47)$.

In conclusion, air pollutant emissions from livestock farms are associated with a reduced lung function level in nonfarming residents of a rural area in the Netherlands. Further research into the impact of emissions from livestock farms, especially on respiratory health of susceptible subgroups (e.g., children, elderly, and respiratory disease patients) is warranted.

Author disclosures are available with the text of this article at www.atsjournals.org

Acknowledgment: The authors thank colleagues of the Institute for Risk Assessment
Sciences for their contribution to the medical examination survey: Marieke Oldenwening, Siegfried de Wind, Amena Magielsen-van As, Saskia Martens, Sigrid Nieuwenweg, Anna Strumphler, Edwina Traanman, and Dorine Verhoef. Jack Spithoven and Nena Burger are acknowledged for handling the biologic samples. Jack Spithoven performed the lgE analyses.

The authors thank Eef van Otterloo for technical support. They thank Stichting Informatie Voorziening Zorg (trusted third party) for ensuring participants' privacy. They thank Ben Bom of the National Institute for Public Health and the Environment for creating the map of the study area.

\section{References}

1. Bauer SE, Tsigaridis K, Miller R. Significant atmospheric aerosol pollution caused by world food cultivation. Geophys Res Lett 2016;43: 5394-5400.

2. Brunekreef B, Harrison RM, Künzli N, Querol X, Sutton MA, Heederik DJ, Sigsgaard T. Reducing the health effect of particles from agriculture. Lancet Respir Med 2015;3:831-832.

3. Lelieveld J, Evans JS, Fnais M, Giannadaki D, Pozzer A. The contribution of outdoor air pollution sources to premature mortality on a global scale. Nature 2015;525:367-371.

4. Sutton M, Howard C, Erisman J. The European nitrogen assessment: sources, effects and policy perspectives. Cambridge: Cambridge University Press; 2011.

5. National Institute for Public Health and the Environment. Veehouderij en Gezondheid omwonenden (Livestock Farming and Neighboring Residents' Health). Publication No 2016-0058. Bilthoven, the Netherlands; 2016.

6. Eduard W, Pearce N, Douwes J. Chronic bronchitis, COPD, and lung function in farmers: the role of biological agents. Chest 2009;136: 716-725.

7. May S, Romberger DJ, Poole JA. Respiratory health effects of large animal farming environments. J Toxicol Environ Health B Crit Rev 2012;15:524-541.

8. Guidry VT, Kinlaw AC, Johnston J, Hall D, Wing S. Hydrogen sulfide concentrations at three middle schools near industrial livestock facilities. J Expo Sci Environ Epidemiol 2017;27: 167-174.

9. Heederik D, Sigsgaard T, Thorne PS, Kline JN, Avery R, Bønløkke JH, Chrischilles EA, Dosman JA, Duchaine C, Kirkhorn SR, et al. Health effects of airborne exposures from concentrated animal feeding operations. Environ Health Perspect 2007;115: 298-302.

10. Dungan RS, Leytem AB, Bjorneberg DL. Concentrations of airborne endotoxin and microorganisms at a 10,000-cow open-freestall dairy. $J$ Anim Sci 2011;89:3300-3309.

11. Thorne PS, Ansley AC, Perry SS. Concentrations of bioaerosols, odors, and hydrogen sulfide inside and downwind from two types of swine livestock operations. J Occup Environ Hyg 2009;6:211-220.

12. Loftus C, Yost M, Sampson P, Arias G, Torres E, Vasquez VB, Bhatti P, Karr C. Regional PM2.5 and asthma morbidity in an agricultural community: a panel study. Environ Res 2015;136:505-512.

13. Loftus C, Yost M, Sampson P, Torres E, Arias G, Breckwich Vasquez V, Hartin K, Armstrong J, Tchong-French M, Vedal S, et al. Ambient ammonia exposures in an agricultural community and pediatric asthma morbidity. Epidemiology 2015;26:794-801.

14. Schinasi L, Horton RA, Guidry VT, Wing S, Marshall SW, Morland KB. Air pollution, lung function, and physical symptoms in communities near concentrated Swine feeding operations. Epidemiology 2011;22: 208-215.

15. Kilburn KH. Human impairment from living near confined animal (hog) feeding operations. J Environ Public Health 2012;2012:565690.

16. Pavilonis BT, Sanderson WT, Merchant JA. Relative exposure to swine animal feeding operations and childhood asthma prevalence in an agricultural cohort. Environ Res 2013;122:74-80.
17. Radon K, Schulze A, Ehrenstein V, van Strien RT, Praml G, Nowak D. Environmental exposure to confined animal feeding operations and respiratory health of neighboring residents. Epidemiology 2007;18: 300-308.

18. Schulze A, Römmelt $H$, Ehrenstein V, van Strien R, Praml G, Küchenhoff $\mathrm{H}$, Nowak $\mathrm{D}$, Radon $\mathrm{K}$. Effects on pulmonary health of neighboring residents of concentrated animal feeding operations: exposure assessed using optimized estimation technique. Arch Environ Occup Health 2011;66:146-154.

19. Hoopmann M, Hehl O, Neisel F, Werfel T. [Associations between bioaerosols coming from livestock facilities and asthmatic symptoms in children]. Gesundheitswesen 2006;68:575-584.

20. Borlée F, Yzermans CJ, van Dijk CE, Heederik D, Smit LAM. Increased respiratory symptoms in COPD patients living in the vicinity of livestock farms. Eur Respir J 2015;46:1605-1614.

21. Smit LAM, Hooiveld M, van der Sman-de Beer F, Opstal-van Winden AWJ, Beekhuizen J, Wouters IM, Yzermans CJ, Heederik D. Air pollution from livestock farms, and asthma, allergic rhinitis and COPD among neighbouring residents. Occup Environ Med 2014;71:134-140.

22. van Dijk CE, Garcia-Aymerich J, Carsin AE, Smit LAM, Borlée F, Heederik DJ, Donker GA, Yzermans CJ, Zock JP. Risk of exacerbations in COPD and asthma patients living in the neighbourhood of livestock farms: Observational study using longitudinal data. Int J Hyg Environ Health 2016;219:278-287.

23. Borlée, F, Yzermans, CJ, Aalders, B, Rooijackers, J, Krop, E, Maassen, K, Schellevis, F, Heederik, D, Smit LAM. "Hotspots" of livestock farms may influence lung function of neighboring residents [abstract]. Eur Respir J 2016;48:OA456.

24. Borlée, F, Yzermans, CJ, Aalders, B, Rooijackers, J, Krop, E, Maassen, K, Schellevis, F, Heederik, D, Smit LAM. "Hotspots" of livestock farms may influence lung function of neighboring residents [abstract]. Environ Health Perspect 2016:1-131.

25. Borlée F, Yzermans CJ, Krop E, Aalders B, Rooijackers J, Zock J-P, van Dijk CE, Maassen CBM, Schellevis F, Heederik D, et al. Spirometry, questionnaire and electronic medical record based COPD in a population survey: comparing prevalence, level of agreement and associations with potential risk factors. PLoS One 2017;12:e0171494.

26. Doekes G, Douwes J, Wouters I, de Wind S, Houba R, Hollander A. Enzyme immunoassays for total and allergen specific $\lg \mathrm{E}$ in population studies. Occup Environ Med 1996;53:63-70.

27. Quanjer PH, Stanojevic S, Cole TJ, Baur X, Hall GL, Culver BH, Enright PL, Hankinson JL, Ip MSM, Zheng J, et al.; ERS Global Lung Function Initiative. Multi-ethnic reference values for spirometry for the 3-95-yr age range: the global lung function 2012 equations. Eur Respir J 2012;40:1324-1343.

28. National Institute for Public Health and the Environment. National Air Quality Monitoring Network, Netherlands. 2016 [accessed 2016 Apr 22]. Available from: http://www.Iml.rivm.nl

29. Beelen R, Hoek G, Vienneau D, Eeftens M, Dimakopoulou K, Pedeli X, Tsai M-Y, Künzli N, Schikowski T, Marcon A, et al. Development of $\mathrm{NO} 2$ and NOx land use regression models for estimating air pollution 
exposure in 36 study areas in Europe: the ESCAPE project. Atmos Environ 2013;72:10-23.

30. Eeftens M, Beelen R, de Hoogh K, Bellander T, Cesaroni G, Cirach M, Declercq C, Dédelè A, Dons E, de Nazelle A, et al. Development of land use regression models for $\mathrm{PM}_{2.5}, \mathrm{PM}_{2.5}$ absorbance, $\mathrm{PM}_{10}$ and $\mathrm{PM}_{\text {coarse }}$ in 20 European study areas; results of the ESCAPE project. Environ Sci Technol 2012;46:11195-11205.

31. Statistics Netherlands. Agriculture; crops, livestock and land use by general farm type, region. 2016 [accessed 2016 Jan 1]. Available from: http://statline.cbs.nl/Statweb

32. Braun-Fahrländer C, Riedler J, Herz U, Eder W, Waser M, Grize L, Maisch S, Carr D, Gerlach F, Bufe A, et al.; Allergy and Endotoxin Study Team. Environmental exposure to endotoxin and its relation to asthma in school-age children. N Engl J Med 2002;347: 869-877.

33. Gehring U, Strikwold M, Schram-Bijkerk D, Weinmayr G, Genuneit J, Nagel G, Wickens K, Siebers R, Crane J, Doekes G, et al.; ISAAC Phase Two Study Group. Asthma and allergic symptoms in relation to house dust endotoxin: Phase Two of the International Study on Asthma and Allergies in Childhood (ISAAC II). Clin Exp Allergy 2008; 38:1911-1920.

34. Carnes MU, Hoppin JA, Metwali N, Wyss AB, Hankinson JL, O'Connell EL, Richards M, Long S, Freeman LEB, Sandler DP, et al. House dust endotoxin levels are associated with adult asthma in a U.S. farming population. Ann Am Thorac Soc 2017;14:324-331.

35. Portengen L, Preller L, Tielen M, Doekes G, Heederik D. Endotoxin exposure and atopic sensitization in adult pig farmers. $J$ Allergy Clin Immunol 2005;115:797-802.

36. Smit LAM, Heederik D, Doekes G, Lammers JWJ, Wouters IM. Occupational endotoxin exposure reduces the risk of atopic sensitization but increases the risk of bronchial hyperresponsiveness. Int Arch Allergy Immunol 2010;152:151-158.

37. Bloemsma LD, Hoek G, Smit LAM. Panel studies of air pollution in patients with COPD: Systematic review and meta-analysis. Environ Res 2016;151:458-468.

38. de Rooij MM, Heederik DJ, Borlée F, Hoek G, Wouters IM. Spatial and temporal variation in endotoxin and PM10 concentrations in ambient air in a livestock dense area. Environ Res 2017;153:161-170.
39. Gehring U, Gruzieva O, Agius RM, Beelen R, Custovic A, Cyrys J, Eeftens M, Flexeder C, Fuertes E, Heinrich J, et al. Air pollution exposure and lung function in children: the ESCAPE project. Environ Health Perspect 2013;121:1357-1364.

40. Williams JE, van der Swaluw E, de Vries WJ, Sauter FJ, van Pul WAJ, Hoogerbrugge R. Modelling the future distribution of ammonium nitrate concentrations in The Netherlands for 2020: the sensitivity to meteorological parameters. Atmos Environ 2015;115: 278-285.

41. Hendriks C, Kranenburg R, Kuenen J, van Gijlswijk R, Wichink Kruit R, Segers A, Denier van der Gon H, Schaap M. The origin of ambient particulate matter concentrations in the Netherlands. Atmos Environ 2013;69:289-303.

42. National Institute for Occupational Safety and Health (NIOSH). Occupational safety and health guideline for ammonia. 1992 [accessed 2017 Jan 1]. Available from: http://www.cdc.gov/niosh/ topics/ammonia/default.html

43. Von Essen S, Romberger D. The respiratory inflammatory response to the swine confinement building environment: the adaptation to respiratory exposures in the chronically exposed worker. J Agric Saf Health 2003;9:185-196.

44. Pérez N, Pey J, Reche C, Cortés J, Alastuey A, Querol X. Impact of harbour emissions on ambient PM10 and PM2.5 in Barcelona (Spain): evidences of secondary aerosol formation within the urban area. Sci Total Environ 2016;571:237-250.

45. Schweizer C, Edwards RD, Bayer-Oglesby L, Gauderman WJ, llacqua V, Jantunen MJ, Lai HK, Nieuwenhuijsen M, Künzli N. Indoor timemicroenvironment-activity patterns in seven regions of Europe. $J$ Expo Sci Environ Epidemiol 2007;17:170-181.

46. Montagne D, Hoek G, Nieuwenhuijsen M, Lanki T, Siponen T, Portella M, Meliefste K, Brunekreef B. Temporal associations of ambient PM2.5 elemental concentrations with indoor and personal concentrations. Atmos Environ 2014;86:203-211.

47. Kim D, Sass-Kortsak A, Purdham JT, Dales RE, Brook JR. Associations between personal exposures and fixed-site ambient measurements of fine particulate matter, nitrogen dioxide, and carbon monoxide in Toronto, Canada. J Expo Sci Environ Epidemiol 2006;16:172-183. 